\title{
Cleaning the Muck of Ages from the Windows InTO THE SOUL of TAX
}

\author{
John Passant* \\ Australian National University, Australia
}

\begin{abstract}
The aim of this paper is to provide readers with an insight into Marx's methods as a first step to understanding income tax more generally but with specific reference to Australia's income tax system. I do this by introducing readers to the ideas about the totality, that is, capitalism, appearance, and form, and the dialectic in Marx's hands. This will involve looking at income tax as part of the bigger picture of capitalism and understanding that all things are related and changes in one produce changes in all. Appearances can be deceptive, and we need to delve below the surface to understand the reality or essence of income and, hence, of income tax. Dialectics is the study of change. By developing an understanding of the processes of contradiction and change in society, the totality, we can then start to understand income tax and its role in our current society more deeply. To do that, we need to understand the ways of thinking and approaches that Marx and others have used. Only then, armed with the tools that we have uncovered, we can begin the process of cleaning the muck of ages from the windows into the soul of tax and move from the world of appearance to the essence of tax.
\end{abstract}

\section{CONTENTS}

I. INTRODUCTION ........................................................... 179

II. Of Icebergs and other Titanic Arguments .................... 182

A. The Tip of the Iceberg ................................................. 184

B. The Sea of Fluidity and the Totality of Life .................... 187

III. Marx's Viewpoint And The Dialectic............................ 188

A. Marx's Viewpoint.................................................... 188

B. Abstraction ............................................................. 190

C. Cleaning the Windows ............................................ 192

* PhD candidate, School of Politics and International Relations, Australian National University A.C.T. AUSTRALIA 0200; former Assistant Commissioner, Australian Tax Office (retired 2008). Contact: en.passant@bigpond.com. 


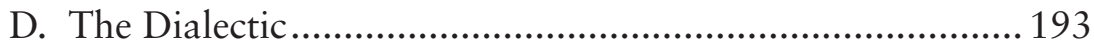

E. Appearance and Reality ...............................................202

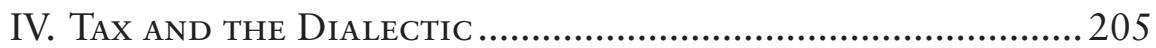

A. The Establishment of Capitalism in Australia and the Imposition of Income Tax....................................206

B. Class Antagonisms in the Tax System ...............................209

C. I'm Walking Backwards for Cacus ....................................2 210

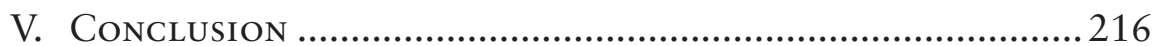




\section{INTRODUCTION}

Drawing on Marx, and those who have followed in his footsteps, this paper introduces readers to a number of related and interrelated approaches and methodologies ${ }^{1}$ for understanding tax and tax reform in Australia. It introduces readers to the idea of depth and hidden meaning in tax. The paper considers tax as part of the societal totality that includes capitalism. In doing this, I hope to make a small contribution to the ways that taxpayers, tax teachers, tax administrators, tax practitioners, politicians, economists, commentators, and interested bystanders can-and do-understand tax in both its specific detail and its position and role within capitalism and, at least partially, in understanding capitalism itself. All are interconnected. They are parts of the same coin if you like. The key is in figuring out how they relate to each other and the whole coin.

Indeed, it is arguable that all three sides of the coin ${ }^{2}$ are themselves reflective of the coin. That is, they are the coin. The coin and its sides make up the area under examination, which is more than the coin and its sides. They are all linked, related, and in constant interaction with each other and the rest of the totality to produce the coin itself. Thus, major tax reform remakes not only the relations within the tax system but also the capital accumulation process and Australian capitalism itself, remembering that the relations that make up Australian capitalism are themselves part of the global system of capitalism and interact within it in a range of ways.

The paper uses concepts such as totality, appearance, and reality and the dialectic process-totality, contradiction, change, all combining other in constant contradictory motion ${ }^{3}$ - to lay the intellectual framework for examining income tax in Australia and to help us get a deeper understanding of the tax system. In doing that, some basic ideas of Marx such as the labor theory of value, surplus value and capital, and the state as a band of hostile brothers can then become tools for a further dialectical examination of the income tax system, taking various areas of that system and, using Marx's

1 There is much debate in Marxist circles about whether Marx, in fact, had a method or even methods. The term here is used to describe the dialectic - totality, contradiction, change - and its application by Marx and others to subsets of the totality of society, including tax, through processes such as abstraction.

2 Who imagined only two sides? Indeed, could coins not be multisided depending on the view one takes of them and what one determines to be a side? For example, a serratededged coin could arguably have many sides. This raises the question of individuationwhat is the unit under examination and is that not also a totality? No, because the totality is society, and we, doing what is humanly possible, examine important subsets of that totality such as the mode of production — capitalism today — and subsets of the important subsets, such as tax.

3 John Rees, The Algebra of Revolution: The Dialectic and the Classical Marxist Tradition 5 (Routledge ed. 1998). 
concepts, abstracting them to better understand them and the system of which they are a part, capitalism. ${ }^{4}$

The tax system is under constant pressure for reform. ${ }^{5}$ It witnesses periodic and cathartic reviews, containing sometimes creatively destructive ${ }^{6}$ proposals for tax reform ${ }^{7}$ which can, at times, produce actual tax reform. ${ }^{8}$ This constant pressure for tax reform and actual tax reform are part of a dialectic of tax that interacts with, and intertwines with, the exploitative system of capitalism that extracts surplus value from workers. ${ }^{9}$ At the same time, the tax system and the tax changes embodied within it waiting to be born or lurking outside in the cold, waiting for an invitation to the warmth inside, impact adversely or encouragingly on the extraction of surplus value, depending on the nature of the reform.

The paper starts in Part II with an introduction to methods of deeper thinking and understanding through looking at an iceberg model developed by a very senior Australian tax officer. This sense of depth is, I believe, a gentle nondialectical introduction to a discussion on the need for dialectical thinking in tax and leads neatly to an examination of Marx's method(s) in Part III.

That section abstracts parts of Marx's methods to make them manageable and digestible. This involves a discussion of Marx's standpointthe working class-and his methods and approaches such as abstraction, cleaning the windows, what the dialectic is in broad terms, and the difference between appearance and reality. The chapter develops key points such as the dialectical understanding of totality and, in situ, the interrelationship between tax and capitalism that underpins, and is a case example of, the intertwining and interconnectedness of things and relationships. Marx's dialectical method and his process of abstraction, "the intellectual practice of breaking [the] whole down into the mental units with which we think about it," ${ }^{10}$ help us do this. The dialectic and the windows of insight it opens into

4 John Passant, Some Basic Marxist Concepts To Help Understand Income Tax, $27 \mathrm{~J}$. JURIS. 263 (2015).

5 Fleur Anderson, Tax Reform Needed to Avert Crisis, Austl. Fin. Rev., Mar. 12, 2014 available at $\mathrm{http} / / \mathrm{www} . \mathrm{afr} . \mathrm{com} / \mathrm{p} /$ national/tax_reform_needed_to_avert_crisis_aToBBTcWP9P2PecK8vdzEK (last visited Jan 7, 2016).

6 Joseph A Schumpeter, Capitalism, Socialism and Democracy 81-86 (George Allen \& Unwin 1943).

7 Ken Henry et al., Australia's Future Tax System Report to the Treasurer (2010) [hereinafter 'the Henry Tax Review'].

8 For example, the Goods and Services Tax came into effect on 1 July 2000 as part of the 'A New Tax System' package.

9 Surplus value is the difference between the value a worker creates and the value of their labor power (or much more crudely, but for the purposes of exposition for nonMarxists, the difference between what workers are paid and the price of the goods and services they create). See Passant, supra note 4, at 269-272.

10 Bertell Ollman, Dance of the Dialectic: Steps in Marx’s Method 60 (2003). Ollman says, "In his most explicit statement on the subject, Marx claims that his method 
the soul of tax may aid our understanding of the Australian tax system and its positioning within capitalism in Australia. Understanding the methodology and approaches gives us the heavy-duty material to clean the windows of the years of neoliberal and Keynesian muck and allows us a better view or views of the subject under consideration. We still have to take the windows to the cleaners, and that is a task for future work.

Using these tools, the paper moves from the real concrete through the process of abstraction to the thought concrete ${ }^{11}$ to argue that understanding tax and tax reform in Australia can only occur fully by understanding capitalism and its processes of change, both within tax but more especially the deeper processes within capitalism that have produced the demands for, and ongoing processes of, tax reform These include the ongoing global economic crises of capitalism, what Andrew Kliman calls the Great Recession, ${ }^{12}$ and, by implication, the resistance that neoliberal policies and the ongoing economic crises have provoked across the globe. ${ }^{13}$ Understanding the income tax system and its interrelations with the rest of economic, political, and social life requires an understanding of how capitalism works to appreciate how the income tax system in Australia works and how the income tax system then shapes the capitalist system as a whole.

The aim of this paper, then, is to introduce readers to Marx's methodological tools, which enable us to begin that process. The last section of the article looks at tax in general through the various windows Marx has given us to help us get a better understanding of the deep rivers that flow through or underneath the seemingly shallow canal of income tax.

In doing this, I stand on the shoulders of the great, people such as Marx, Engels, Lukács, Ollman, and others. They have done the general theoretical work. The task is then to apply their insights and methodologies to tax in Australia to understand that part of the totality, that is, tax, and the totality itself-in this case, capitalism in Australia or, more appropriately, capitalism as it exists and operates in Australia.

starts from the 'real concrete' (the world as it presents itself to us) and proceeds through 'abstraction' (the intellectual activity of breaking this whole down into the mental units with which we think about it) to the 'thought concrete' (the reconstituted and now understood whole present in the mind) (Marx, 1904, 293-94). The real concrete is simply the world in which we live, in all its complexity. The thought concrete is Marx's reconstruction of that world in the theories of what has come to be called 'Marxism.' The royal road to understanding is said to pass from the one to the other through the process of abstraction." The reference to Marx 1904 is a reference to KARL MARX, A Contribution to the Critique of Political Economy 293-294 (N. I. Stone trans., Int'l Library Publ'g 1904).

11 Id. at 60.

12 Andrew Kliman, The Failure of Capitalist Production: Underlying Causes of the GREAT ReCESSION 1-3 (2011).

13 Tunisia, Egypt, Syria, Libya, Bahrain, Greece, Spain, Portugal, Italy, Venezuela, Ukraine, Thailand, and Bosnia all come to mind in varying degrees. 
Let's start on this journey by looking at a simple model drawn from the work of a very senior member of the Australian Tax Office (ATO) as a way of introducing us to depth and tax simultaneously.

\section{Of Icebergs and other Titanic Arguments}

As tax teachers, lawyers, and accountants, it can seem that we are forever destined to deal in minutiae. Yet even at a basic level-for example, when we are debating the meaning of words in a tax statute-the Commonwealth Acts Interpretation Act 1901 and judicial approaches exhort us and force us to look at extraneous material to understand the "real" meaning of the words to which Parliament has given its often unknowing and, I would suggest, unknowable imprimatur. The process of "looking behind" the words of the statute involves examining, among other things, second reading speeches, and explanatory memoranda. The process of looking behind, going deeper, is about understanding the policy and context for the particular laws that helps us understand the provisions. However, we do this at a superficial level. We hardly ever allow capitalism-a specific and transitory mode of production $^{14}$ - and its reality to be part of that discussion. It doesn't enter our heads. Discussions about "the economy" are framed, at least in the tax field, not in terms of accumulation and exploitation but at the level of policy. They are caught in the often sterile debates about efficiency and equity without ever asking whose interests efficiency serves and why inequality exists and is growing..$^{15}$ We reinforce the current relations of production by never questioning them in their totality or their expression within our own particular area of expertise and enquiry, in this case tax. As Harman argued:

A social group identified with the continuation of the old relations of production and the old institutions of the superstructure necessarily only has a partial view (or a series of partial views) of society as a whole. Its practice is concerned with the perpetuation of what already exists, with 'sanctifying' the accomplished fact. Anything else can only be conceived as a disruption or destruction of a valuable, harmonious arrangement. Therefore, even at times of immense social crisis, its picture of society is one of a

14 Brian Roper, The History of Democracy: A Marxist Interpretation 10-11 (2013).

15 Andrew Leigh, Battlers and Billionaires: The Story of Inequality in Australia (2013); Joseph E. Stiglitz, The Price of Inequality: How Today's Divided Society ENDANGers Our Future (2012). 
natural, eternally recurring harmony somehow under attack from incomprehensible, irrational forces. ${ }^{16}$

We tax teachers, tax administrators, tax policy wonks, and tax practitioners are, as Harman said, concerned with sanctifying the accomplished fact-in this case, the accomplished fact of capitalism and the role of tax within it. As Hegel told us, the owl of Minerva flies only at dusk. ${ }^{17}$ For many of us, however, there is no take-off. The very work we do, and its nature, does that because we are concerned with the current relations of production, not understanding how they arose or concerning ourselves with future ones. It also does that because we don't discuss capitalism per se and its relationship to tax. Nor do we discuss tax and its relationship to the totality, that is, society, and an important part of that totality, the mode of production-in our case, capitalism. I see my task as helping others and myself take flight, not just at dusk or even, looking forward, at dawn, but at all times.

We must not only look back, like the owl of Minerva. We must look forward. Indeed, what is in view contains the past, the present, and possible futures. Ollman argued that history for Marx, and this is something that equally applies to tax and tax research, "refers not only to time past but to future time. Whatever something is becoming-whether we know what that will be or not-is in some important respects part of what it is along with what it once was." ${ }^{18}$ It is the idea of becoming, of constant change, arising because "existence itself is an uninterrupted process of transformation," 19 that is, a key Marxist way of looking at and understanding the capitalist world and its components-areas such as tax. It shows both the possibilities of change within the system under examination and the ability to transcend those limits and create a new paradigm from the

16 Chris Harman, Base and Superstructure, 2 InT'L Socialism 3, 30 (1986) available at http://www.marxists.org/archive/harman/1986/xx/base-super.html (last visited Jan 7, 2016).

17 "When philosophy paints its grey in grey, one form of life has become old, and by means of grey it cannot be rejuvenated, but only known. The owl of Minerva takes its flight only when the shades of night are gathering." G. W. F. Hegel, Philosophy OF Right 20 (S. W. Dyde trans., Batoche Books Ltd. 2001). Hegel was arguing that analysis could occur only after the event. However, if the event contains within itself possible futures, then a dialectical materialist approach might enable us to understand the present and the possibilities contained in it, based in part on what the event is now and was before, acknowledging that the "is now" and the "might be" can only be understood through the "was before."

18 Bertell Ollman, Putting Dialectics to Work: The Process of Abstraction in Marx's Method, in 3 Rethinking Marxism: A Journal of Economics, Culture \& Society 26, 32 (1990).

19 Leon Trotsky, The ABC of Materialist Dialectics, in The Age of Permanent Revolution: A Trotsky Anthology 355, 356 (Isaac Deutscher ed., 1964). 
contradictory elements within the system itself. ${ }^{20}$ This also means understanding capitalism, not just in general but also "a given capitalism at a given stage of development." ${ }^{21}$ It also means understanding that the parts of the whole interact with each other and are, thus, constantly changing the totality and themselves.

To do that, let's start off with an analysis of tax complexity not from a Marxist point of view but from that of a senior tax officer, and one of the few who has made any attempt to go beyond platitudes about the purpose and policy of tax laws or proposed laws to try to contextualize tax in Australia. I offer this example because it shows that it can be done and is, I believe, a way of introducing readers to more complex Marxist approaches, in particular the dialectic, to help understand tax.

\section{A. THE TIP OF THE ICEBERG}

ATO Deputy Commissioner Jim Killaly has sought to understand the depth of tax, including different worldviews which, he argued, drive and interact with the actions of players in the tax system. He is, in my experience, one of the best strategic thinkers in the ATO today. ${ }^{22} \mathrm{He}$ showed us that we can delve deeper to understand the drivers of change in a tax context, even if not in the Marxist terms that I have outlined earlier. His analysis showed that we can go further in our thinking about tax than just the oftrepeated but never fully understood attempts of many tax teachers and other to teach and understand tax in its "political, social, and economic environment." Such an approach is, or can be, static and uncomprehending of change. Killaly talked in terms of the iceberg model with events or things that happen-the surface appearance-at the top of the iceberg, patterns and trends underneath them, structural drivers below that and world views at the very bottom, all in increasing size. ${ }^{23}$ Here is his pictorial representation of the iceberg.

20 These ideas of totality, change, and contradiction are, as we shall soon see, at the heart of the dialectic. See Rees, supra note 3, at 5.

21 Trotsky, supra note 19, at 357.

22 I worked in Large Business and International in the Australian Tax Office when Jim was the Deputy Commissioner in charge. His leadership, and the Strategic Leadership program he set up, gave me hope for the ATO.

23 Jim Killaly, Deputy Commissioner of Taxation, ATO, Strategic leadership in a technical and policy delivery environment: The Tax Office experience of compliance management in the large business sector, 2009 Medicare Leader Series Comparative StudIES In Complance Management (May 28, 2009), PowerPoint 20 available at http:// www.slidefinder.net $/ \mathrm{m} /$ medicare-speech-2805091/33027059 (last visited Jan. 7, 2016). Killaly's diagram is an adaptation of earlier work done by others, including RICHARD Hames, The Five Literacies OF Global Leadership 287 (Jossey-Bass 2007). His adaptation was done in the course of his role as a Deputy Commissioner in the Australian Taxation Office. 


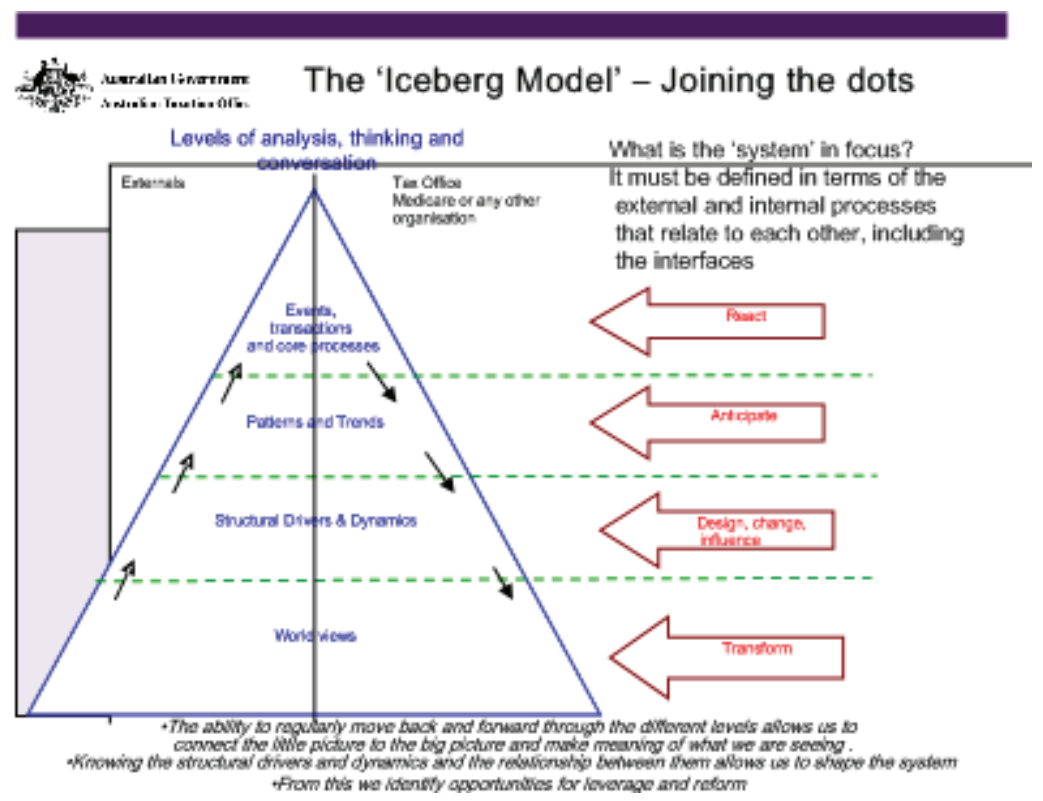

In this, Killaly prefigured, paradoxically after the event, Marx and his search for the essence rather than the appearance of a thing or, more appropriately, the thing as a relation. For example, Marx begins Volume One of Capital with a discussion of the commodity as a way of unraveling its essence as a social relation under capitalism. It encompasses, among other things, the concept of use and exchange values, the purchase and sale of labor power, the exploitative relationship of capital over labor that produces the commodity, the surplus value embedded in it, and the profit that flows from its exchange. The concrete is abstracted to reveal the essence, a complex set of interrelationships between human beings in a complicated and interconnected hierarchy of economic, social, and political life and power that can then be used to understand the real concrete through the prism of the abstract.

To emphasize the idea of interconnectedness, here is what Killaly said at the bottom of the slide:

The ability to regularly move back and forward through the different levels allows us to connect the little picture to the big picture and make meaning of what we are seeing. Knowing the structural drivers and dynamics and the relationship between them allows us to shape the system. From this, we identify opportunities for leverage and reform. ${ }^{24}$ 
While this shows a dialectical understanding of relationships, it lacks systemic depth and an understanding of class and the relentless drive for profit and the reinvestment of that profit, that is, the Grundnorm of capitalist production or-as Marx put it- "Accumulate, accumulate! That is Moses and the prophets." ${ }^{25}$ Killaly also failed to recognize class struggle as the driver of major change within, and potentially beyond, capitalism. ${ }^{26}$

Talk of class struggle conjures up visions of strikes and picket lines. However, both sides of the class divide can, and do, wage class struggles. The past 30 years of neoliberalism and working class quiescence in Austral$\mathrm{ia}^{27}$ and much of the developed world can best be described as a one-sided class war by capital against labor. ${ }^{28}$ The old mole of sometimes open, often hidden, class struggle ${ }^{29}$ does not live on, or in, or even near the iceberg. Perhaps it is too cold or perhaps, like Hardt and Negri, ${ }^{30}$ Killaly thinks the old mole is dead, frozen in the icy wastelands of modernity.

When Killaly in his iceberg model posits worldviews as the base, he adopts an idealist approach rather than a materialist one to understanding the world. Ideas come from, and reflect, a material base. As Marx wrote: "It is not the consciousness of men that determines their being, but, on the contrary, their social being that determines their consciousness." ${ }^{31}$ However, we need to avoid reading this as some sort of reductionist manifesto from Marx. As Lukács argued, the idea of totality—-that society is a totality, and that each part of it interacts on the other parts and the whole-not only

25 Karl Marx, Capital Vol. 1: A Critique of Political economy, 558 (Frederick Engels ed., Samuel Moore \& Edward Aveling trans., Progress Publishers, 1977) (1867).

26 As Marx and Engels say: "The history of all hitherto existing society is the history of class struggles.” Karl Marx \& Friedrich Engels, The Communist Manifesto (Wordsworth Editions Ltd, 2008) (1848).

27 John Passant, Neoliberalism in Australia and the Henry Tax Review 8 J OF THE AustraLasian TAX TEACHers Ass'N 117, 120-123 (2013).

28 Sharon Smith, Marxism, Unions and Class Struggle: The Future in the Present 78 InT'L SoCIALIST REv. (2011) available at http://www.isreview.org/issues/78/feat-marxism\&unions. shtml (last visited Jan. 7, 2016).

29 Karl Marx, The Eighteenth Brumaire of Louis Bonaparte 107 (Int'l Publishers 1938).

30 Although arguing against Marx and claiming that his old mole of class struggle was dead, Hardt and Negri say this by way of explanation of Marx's view of the old mole. "Marx tried to understand the continuity of the cycle of proletarian struggles that were emerging in nineteenth-century Europe in terms of a mole and its subterranean tunnels. Marx's mole would surface in times of open class conflict and then retreat underground again - not to hibernate passively, but to burrow its tunnels, moving along with the times, pushing forward with history so that when the time was right, $(1830,1848$, 1870 ) it would spring to the surface again. 'Well grubbed old mole!'” Michael Hardt \& Antonio Negri, Marx's Mole is Dead! Globalisation and Communication, EuRozINE

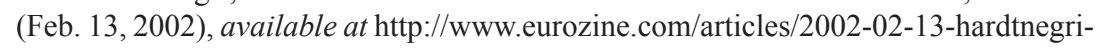
en.html (last visited Jan. 7, 2016).

31 Karl Marx, Preface to a Contribution to the Critique of Political Economy, available at https://www.marxists.org/archive/marx/works/1859/critique-pol-economy/prefaceabs.htm (last visited Jan. 7, 2016). 
negates reductionism but also is the essence of Marxism. ${ }^{32}$ Rees, too, argued for similar reasons that totality means there can be no reductionism but adds this is also the case because a dialectical approach "presupposes the parts and the whole are not reducible to each other." ${ }^{33}$

Killaly's iceberg model is useful in pointing out that there are deeper forces at work in tax than just the surface happenings or events or the policy rationalizations or even worldviews. Let's build on that to move into a discussion about totality and change.

\section{B. The Sea of Fluidity and the Totality of Life}

The second aspect that Killaly's model doesn't address is the context in which the iceberg finds itself. To continue the analogy, we need to understand not just the iceberg but also the sea in which it floats and is submerged, and the world that sea is in and of which it is a part. Processes such as global warming and the creation and destruction of icebergs would be included in that.

So instead of looking just at the tip of the tax iceberg, tax teachers, administrators, and practitioners need to-indeed must-explore the submerged tax mass. However, they have to go further (and to give him his due, Killaly does do this in other parts of his presentation and slides ${ }^{34}$ and examine the societal, political, and economic sea in which the iceberg floats, the tides, eddies, and currents that move tax icebergs around. They also need to examine the process of creation and destruction of such structures in a rapidly changing environment to understand the tip and the mass beneath and how the iceberg came to be, where it is, its environment, the pressures, and forces moving it and which it moves, and the internal contradictions tearing it apart and rebuilding it. This also means understanding that the tip and the rest of the iceberg are part of that sea, interact with it, and help create and recreate it, in single and multiple effects. In essence, understanding the tip of the iceberg means understanding the iceberg and the sea it is in. This also requires an understanding of the sea as part of a wider system, the planet, and its ecology. ${ }^{35}$ This analogy of examining the planet, sea, iceberg, and tip to see how they interact and interrelate is understanding that these exist in the context of and interrelate with the rest of the universe, in short Marx's concept of totality.

32 Georg Lukács, History and Class Consciousness 27 (Merlin Press 1967).

33 Rees, supra note 3, at 7.

34 See Killaly, supra note 23, slides 5 and 6, where he talks of the interrelatedness of the big perspectives. The perspectives that he identified are social, economic, political, technological (ways of knowing, doing, understanding), environmental, tonal (the pervading ethical issues and perspectives), and tax technical (SEPTETT).

35 For a brilliant explanation of Marx and the environment, see JoHn BELlamy Foster, MarX's Ecology: Materialism AND Nature (2000). 


\section{MarX's ViewPoint AND THE DiALECTIC}

Before we address the question of the dialectic, to understand it, we must first understand the point of view, the window or windows-into society that those thinking in this way adopt.

\section{A. MarX's VIEWPOINT}

Marx sees the world through the eyes of the working class. His view is not, it is true, as a worker but in the context of capitalism and its transitory nature and the role of the working class in becoming the subject of history rather than just its object, or the subject-object of history, as Lukács puts it. ${ }^{36}$ Bertell Ollman used the reverse of an old English lyric to explain the basic viewpoint of Marxists as compared to others, especially in academia:

The law locks up the man or woman

Who steals a goose from off the common,

But leaves the greater villain loose

Who steals the common from under the goose. 37

The commons, of course, was the land owned by everyone in the village. By the late Middle-Ages, feudal lords were claiming this land as their own private property. In universities today, we can discern two opposing kinds of scholarship - that which studies the people who steal a goose from off the commons ... and that which studies those who steal the commons from under the goose ... If the 'mainstream' in practically every discipline consists almost entirely of the former, Marxism is our leading example of the latter. ${ }^{38}$

Marxists study not just the ruling class but attempt to understand why they are the ruling class. They examine the processes of history that saw them become the lords ruling over the commoners and commons, bosses over workers, and the relations that make them the rulers. They investigate particular areas from the viewpoint of the working class as both the object and the subject of history. They have a materialist approach, and for this reason, the dialectic is sometimes referred to as historical materialism precisely because Marxists look to the way human beings organize production to help understand that society. As Lukács said, "historical materialism alone is in a position to offer objective and correct knowledge of capitalist society. It

36 Lukács, supra note 32, at 149.

$3715^{\text {th }}$ century, English, Anonymous, quoted by Ollman, supra note 10, at 155 .

38 Ollman, supra note 10, at 155. 
does not deliver this knowledge independently from the class standpoint of the proletariat, but rather precisely from this standpoint." 39

What changes the class from being the object of history to its subject? As Marx and Engels famously put it, "the history of all hitherto existing society is the history of class struggles." ${ }^{40}$ This understanding, this historical materialism, can help the working class move toward an alternative vision and practice of society, one already rooted in the present society and bought within view by the contradictions within that society. Of course, working class struggle and its level of intensity define that understanding but practice without theory is as doomed to failure as theory without practice.

For workers, class analysis, class consciousness, and struggle are intimately mixed and this holds true in tax, too. It is no surprise that the dominant capitalist ethos and ideology of neoliberalism has captured tax and tax policy ${ }^{41}$ at a time of declining global profit rates and, in Australia, a massive decline in strike days lost (in other words, a big drop in open class struggle). ${ }^{42}$

As to processes and tax analysis and teaching, for example, Ollman said that it is easy to see the thief taking the goose but the theft of the commons is more difficult to see, because it occurs over time as part of a process. ${ }^{43}$ We have to grasp the bigger picture-why landlords began to claim that the commons were private property, changes within feudalism, the first stirrings of capitalism, and so on to understand the specifics in more detail. It is much the same with the theft of the tax commons in the realm of real thought through the appropriation by capital of surplus value created by workers, and in the domain of the real concrete through tax cuts for highincome earners and capital and tax expenditures worth tens of billions for the rich and powerful, as well as shifts in tax bases from income to consumption. What we don't see so clearly is the systemic loss of tax from the rich and capital. What we don't see at all is the extraction and appropriation of surplus value by capital from labor and its realization on the market as profit, rent, interest, dividends, and the ongoing purchase of labor through wages, all of which underpin and make viable the tax system. ${ }^{44}$ We do not recognize the tax commons because they have already been stolen. That is why arguments for tax equity under capitalism are ultimately a fraud. This doesn't mean that progressive tax changes, if implemented, can't make life better for workers. They can. It just means capital will resist such changes because it may result in less surplus value in concrete form for them. To achieve a better tax system for workers will require class struggle by labor to impose it on capital. Even if that occurs, however, and capitalism remains

39 Georg Lukács, A Defence of History and Class Consciousness: Tailism and the DiaLECTIC 80 (Verso 2002).

40 MarX \& Engels, supra note 26, at 1.

41 Passant, supra note 27, at 117.

42 Tom Bramble, Trade Unionism in Australia: A History From Flood to Ebb Tide 7 (2008); Passant, supra note 27, at 120-124.

43 Ollman, supra note 10 , at 155.

44 Passant, supra note 4, at 277-85. 
intact, the fundamental inequity of capitalism, the exploitation of the working class by capital, is not abolished. Tax arises after exploitation and the extraction of surplus value occur. It is built on that exploitation and so cannot fundamentally challenge it.

\section{B. AbStRACTION}

According to Ollman, because capitalism is so big and so all-powerful, few of us see it. ${ }^{45}$ As he said, in explaining why abstraction is a part of the thinking process: "our minds can no more swallow the world whole at one sitting than can our stomachs." 46 Another reason for abstraction is to move from the appearance to the reality, from appearance to essence, or real concrete to thought concrete to use different descriptions of the process.

Certainly, when we are thinking about tax, capitalism, its structure, and arrangements are assumed as the eternal background, the natural wellspring of taxable income in the hands of capital and labor. Like the almost automatic process of breathing the air around us, we often only question the process when the air is poisoned. The complex interrelations and the process of change within the system blind us to the reality, ${ }^{47}$ that is, the totality and its expression in important areas such as the mode of production-capitalism today-and subsets such as tax and tax reform. As a tool, dialectics can help us understand the totality that exists and the interrelationships between the differing parts that make up the whole, and the feedback loops of interpenetration that exist between the whole and the parts that make it up.

Abstraction is a key process for Marx and Marxists. Marx explained his method of political economy in the following way:

It seems to be correct to start with the real and concrete, the actual prerequisites, thus in economics, e.g., with population, which is the basis and the subject of the whole social process of production. Yet, on closer consideration, this proves to be wrong. The population is an abstraction if, for instance, I omit the classes of which it is composed. These classes, in turn, remain an empty phrase if I am ignorant of the elements on which they are based, e.g., wage-labor, capital, and so on. These presuppose exchange, division of labor, prices, etc. For example, capital is nothing without wage-labor, without value, money, price, etc. If, therefore, I were to start with population, it would be a chaotic idea of the whole and through more precise determination I would arrive analytically at increasingly simple concepts; from the concrete as imagined to increasingly tenuous abstractions until I reached the most simple determina-

45 Ollman, supra note 10 , at 156.

46 Id. at 60.

47 Id. 
tions. From there it would be necessary to take the journey again backwards until I finally arrived at population again, but this time not as a chaotic idea of a whole, but as a rich totality with many determinations and relations. ${ }^{48}$

In other words, as Ollman puts it, we move from the real concrete to the thought concrete through abstraction. ${ }^{49}$ Thus, in the tax field, we might move from taxable income to tax profit to accounting profit to surplus value to understand better the taxable income of companies. We might also move from the company as taxpayer taxed on its taxable income to examine the processes by which the wealth that workers create-the surplus value that is embedded in profit-is expropriated by the owners of capital and how it becomes translated into profit, and what happens to that profit in the process of accumulation and repurchase of labor power and capital. The abstraction has already occurred-surplus value is an abstraction, for example-but its existence in thought, together with the circulation process and the sale of goods and services on the market, makes our understanding of profit more complete. We have investigated the appearance and found the essence. It was Marx who said that the appearance of reality was capital producing profit, labor producing wages, and land producing rent, or the Trinity Formula of political economy as he less than generously called it. ${ }^{50}$ For him, however, the source of these categories was expressions of a more general essence. They were all drawn from surplus value, essentially the unpaid labor of workers in the production of goods and services for the market. Value is an expression of the socially necessary labor time inhered in a product.

The income tax system reflects that fundamental contradiction ideologically by assuming capitalists earn their profit, interest, rent, and the like rather than it flowing from labor. Indeed, income tax in Australia is theorized and based on three categories of income-income from labor, income from property, and income from business-a combination of both labor and capital. ${ }^{51}$ The ghost of Adam Smith haunts tax not just through his four principles but through his Trinity, a mystification of income based on the surface reality.

Income tax also applies after the event-that is, after the process of realization on the market occurs. This produces profit and this can be reinvested as capital to purchase labor power again. The tax system is predicated on the "reality" or the "fact" that workers are paid for their labor rather than their ability to labor or their labor power. It does this by both following the Trin-

48 Karl MarX, A Contribution to the Critique of Political Economy 129-130 (General Books 2009).

49 Ollman, supra note 10, at 60.

50 III Karl Marx, Capital. A Critique of Political Economy 814 (Progress Publishers 1974).

51 For a more tax-technical discussion of these categories, see John Passant et al., Are Returns Received by Householders from Electricity Generated by Solar Panels Assessable Income? 43 Austl. TAX Rev. 263, 269 (2014). 
ity Formula for income and developing a category called taxpayer to whom is assigned, in the case of business, the responsibility of tax on the value in real form they have expropriated or exploited from workers. In addition, the revenue that government raises will be used for capitalist purposes-for example, infrastructure for capital, tax expenditures on business and the rich, and the social wage to produce educated and healthy workers to exploit.

The contradiction is also fought out politically and economically in terms of the real appearance over which class bears the tax burden. Of course, if tax is an extraction from surplus value, then the answer is that the state becomes a further extractor of surplus value, at the expense-so capital sees it-of a greater share for them. Thus, the introduction and expansion of consumption taxes could be seen, even if it occurs in conjunction with tax cuts for all, including business, as a shift from taxing capital to taxing labor. In part, this will be because inflation over time will increase the average tax rate as workers go into higher tax brackets while for business, the flat rate remains just that-a flat rate.

Obviously, neither capital nor the vast majority of labor see tax as an extraction from surplus value. The tax system reflects the individualization of the distribution of surplus value in money form into particular hands. The particular nature of the distribution that occurs depends on whether one owns the means of production or one only has one's labor power to sell to capital to survive. Despite the fact that there is not a level of understanding of the essence of taxation, the real concrete remains real, but that, too, has consequences. A number of revolutions-for example, the French Revolution and the American Revolution-had, as one of their immediate sparks, taxation. The Henry Tax Review was, in the main, a neoliberal argument for a further shift in tax, at the level of the real concrete, from capital to labor. ${ }^{52}$ There also may be conflict within the capitalist class over industry tax burdens and some sectors, for example, primary industry and mining, may receive more favorable taxable treatment than other areas.

\section{Cleaning the Windows}

David Harvey has also given us a very insightful way of looking at Marx's approach. He understood that Marx's relational approach means nothing is fixed and no concept can be understood in isolation. ${ }^{53}$ Borrowing from Ollman, he said “... Marx sees each relation as a 'separate' window from which we can look in upon the inner structure of capitalism." ${ }^{44}$ If we view capitalism from just one window, it appears "flat and lacks perspective." 55 We move to another window and see things previously hidden so that " $[\mathrm{b}]$

\footnotetext{
52 Passant, supra note 27.

53 David Harvey, The Limits to Capital 2 (1982).

54 Id.

55 Id.
} 
y moving from window to window and carefully recording what we see, we come closer and closer to understanding capitalist society and all of its inherent contradictions." ${ }^{56}$ Such an approach in tax, for example, might examine and construct an understanding of Australian income tax and capitalism through that examination and abstraction. However, we bring the thinking of the past to this process. We need to clean the windows to see more clearly what is beyond. This paper, I hope, contributes to that window cleaning, recognizing that the heavy-duty cleaning material already exists. All we need to do is to use that material to clean the windows. In other words, the conceptual framework already exists. What is needed is to apply that framework to income tax, in my case using the income tax system I am familiar with, that in Australia. Because the income tax systems of the developed capitalist countries have similar bases-for example, income, taxpayer, resident, source, with variations-the tools outlined in this article for cleaning the muck of ages from the windows of tax are more generally applicable to those income tax systems. They are similar to that of Australia.

We cannot really clean the windows without looking at class and class struggle, or lack of it, the creation of surplus value, the circulation processes in capitalism, the transformation of value into prices, disruptions to the "natural" distribution of surplus value, both the complementary and antagonistic nature of the capitalists who make up the capitalist class, the claims of different sections of capital and the state to a share of surplus value, the tendency of the rate of profit to fall, to name just a few concepts to help us on our long journey to tax enlightenment. We can view tax through these numerous windows, wiping clean the muck of ages ${ }^{57}$ for a better view and, in turn, developing a better understanding not just of income tax in Australia but of Australian capitalism and the totality, that is, society.

The dialectic is a way of understanding the process of change, including in tax. What, then, is this dialectic everyone isn't talking about?

\section{The Dialectic}

Like all good dialecticians, the parts have been partially revealed in our previous discussion. To concretize our thinking, Birchall said: "Dialectics ... is the study of how things change." 58 It is also understanding that "things"

56 Id.

57 Karl Marx and Friedrich Engels, The German Ideology available at https://www. marxists.org/archive/marx/works/1845/german-ideology/ch01d.htm (last visited Jan. 7, 2016). This cleaning away of the muck of ages will occur, according to Marx and Engels, during a workers' revolution. In changing the world, workers change themselves.

58 Ian Birchall, What's in a Word: Dialectics: The Whole Truth, SocialisT REviEw 27-30 (1982-1983) available at http://www.marxists.org/history/etol/writers/birchall/1982/12/ dialectics.htm (last visited Jan. 7, 2016). 
are processes, or-as Engels put it- "the world is not to be comprehended as a complex of ready-made things, but as a complex of processes." ${ }^{59}$ Nothing is final. All is in the process of not only becoming but also ending, or as Engels said:

Just as the bourgeoisie by large-scale industry, competition, and the world market dissolves in practice all stable time-honoured institutions, so this dialectical philosophy dissolves all conceptions of final, absolute truth, and of absolute states of humanity corresponding to it. For it (dialectical philosophy), nothing is final, absolute, sacred. It reveals the transitory character of everything and in everything. Nothing can endure before it except the uninterrupted process of becoming and passing away, of endless ascendancy from the lower to the higher. ${ }^{60}$

This complex of processes occurs within a totality so a change in one part of the totality produces changes in the rest of the parts because of their interconnectedness and, thus, in the totality. The totality is society. ${ }^{61}$ However, even this can be too schematic because there is a constant process of change going on, brought about by contradictions within the totality itself, and interacting back upon each other and the whole, with the whole also interacting upon the parts. It is not just that the whole is great than the sum of its parts. The parts are greater than their own uniqueness by being part of the whole. A single worker is powerless but has the potentiality of power. Thus, together as a class, workers can make a revolution and, in doing that, create a new society. As Birchall said: "So, rather than the whole being a simple sum of its parts, the parts can be understood only in the context of the whole. As Lenin points out, a hand is only really a hand if it is part of a body." 62

Tax is a very handy part of the body of capitalism. There is a duality to tax in this sense. It is levied by the state and, whatever else may and can be said about the state, and many careers have been built on just this enquiry, the state under capitalism remains a capitalist state. However, tax is levied after the event-that is, after surplus value is created and appropriated. More than that it is levied after the circulation process has seen the capitalists realize profit, or interest or dividends or rent, and the profit is then capital again, to be used among other things to buy labor power (living capital) and machines, buildings, etc. (dead labor). Tax is levied during the process of the distribution of surplus value, which capital regards as its property, its

594 Friedrich Engels, Ludwig Feuerbach and the End of Classical German Philosophy (Paul Taylor trans.) available at https:/www.marxists.org/archive/marx/works/1886/ ludwig-feuerbach/ch04.htm (last visited Jan. 7, 2016).

${ }^{60}$ Id. at Part 1, available at http://www.marxists.org/archive/marx/works/1886/ludwigfeuerbach/ch01.htm (last visited Jan. 7, 2016).

61 Lukács, supra note 32, at 27.

62 Birchall, supra note 58. 
worth, its earnings, its income and, as part of the process of realizing surplus value in concrete form, as profit, rent, interest, and so on. Tax upsets the natural order of things from the point of view of the capitalist because it subtracts from their "return on investment", that is, the amount they have invested or reinvested in the means of production and labor power.

Further, tax itself, and tax reform, if implemented, and depending on the nature of the reform, can produce changes in the relationships within capital or sectors of it, between capital or parts of it and the state, ${ }^{63}$ between labor and capital, and impact markedly (both positively and negatively and in whole or in part) on the capital accumulation process. Such reforms may change the share of surplus value appropriated by individual capitalists or industries in the process of capitalist production, realization, and distribution and reproduction, the further purchase of labor power and the means of production for the ongoing processes of capitalism to continue. And, of course, static tax laws may become obstacles to the accumulation of capital over time because of shifts in the nature of production, falls in global profit rates, the degree of internationalization of an economy, and the competitive pressures that brings to bear, often with ideologies of cutting taxes, grabbing the imagination of some or most politicians and parts of the population, such as small business in general and that section of big business which is part of global capital and, of course, the final consideration, the combativity, or lack of it of the working class.

Tax will influence, in direct and indirect ways, the production of surplus value and its distribution as profit, interest, rent, dividends, and wages. At a micro level, sections of capital, for example, which see their profit being taken by the state might change their residence or earning location and use $19^{\text {th }}$ century tax treaty concepts to avoid tax in seemingly higher taxing jurisdictions such as Australia (one example of base erosion). Google made between $\$ 1$ and $\$ 2$ billion in revenue from Australian sources in a recent income year but paid, on one estimate, only $\$ 74,000$ in tax here. ${ }^{64}$ Apple generated \$26 billion worth of revenue from Australia over 10 years to 2013 and yet the company only paid $0.7 \%$ of its revenue in tax here. ${ }^{65}$ In addition to base erosion, high purchase prices for intellectual property, in other words possible profit shifting, and double Irish Dutch sandwiches-moving profit through Ireland to the Netherlands and back through Ireland, all tax free on the way to a tax haven-reveal complex arrangements whose sole objective is to keep the surplus value rendered as profit in the hands of the company exploiting its workforce or retailing those products to consumers.

63 See Passant, supra note 27, at 125-26.

64 John Passant, Giant Profits, Tiny Tax Bills: Time to Close Loopholes on Corporate Tax Avoidance, The Conversation Nov. 22, 2012 available at http://theconversation.com/ giant-profits-tiny-tax-bills-time-to-close-loopholes-on-corporate-tax-avoidance-10874 (last visited Jan. 7, 2016).

65 Neil Chenoweth, How Ireland Got Apple's \$9bn Profit, Australian Fin. Rev., 6 Mar. 2014, 1 available at http://www.afr.com/p/technology/how_ireland_got_apple_bn_ profit_erlmHONvoHJGixwLUpFckN (last visited Jan. 7, 2016). 
As Google chairperson Eric Schmidt said, in defending his company's tax avoidance activities around the globe, activities that saw it funnel almost $\$ 10$ billion into Bermuda, saving $\$ 2$ billion in taxes:

I am very proud of the structure that we set up. We did it based on the incentives that the governments offered us to operate. The company isn't about to turn down big savings in taxes. It's called capitalism. We are proudly capitalistic. I'm not confused about this. ${ }^{66}$

In other words, for business, tax laws become part of the structure of capitalism and paying tax is a cost to business. The competitive drive to lower costs and secure more profit for each individual business means that company tax "planning" or avoidance is not a failing of capitalism. It is its logical expression. It is not something that can be legislated away. It is inherent to individual capital in a competitive capitalist society. So, too, arguably are the judiciary's ideas or even world views of community and the individual that underpin differing judicial approaches to the various general anti-avoidance provisions in Australia. ${ }^{67}$

How, then, does the dialectical method ${ }^{68}$ help us understand all of this? First, let's examine what is covered by the term the dialectic. Because the audience for this article is those with an interest in tax rather than a deep grounding in Marxism, I will try to keep this discussion as easy to understand as possible. My apologies in advance if sometimes I fall short of that goal.

As Lenin said, "[t]he splitting of a single whole and the cognition of its contradictory parts is the essence (one of the 'essentials,' one of the principal, if not the principal, characteristics or features) of dialectics." ${ }^{69}$ Partly, this is done because as I mentioned before "[o]ur minds can no more swal-

${ }^{66}$ Brian Womack, Google Chairman Says Android Winning Mobile War With Apple:

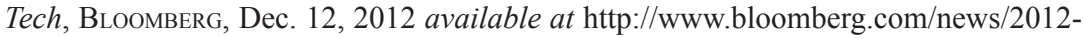
12-12/google-chairman-says-android-winning-mobile-war-with-apple-tech.html (last visited Jan. 7, 2016).

67 John Passant, Tax Avoidance in Australia: Results and Prospects, 22 Fed. L. Rev. 493, 523 (1994).

68 'Dialectical materialism' is a term used and abused by the Stalinist regimes to turn creative thought into a crude rubber stamp for state capitalist dictatorship. See Birchall, supra note 58. The term "The Dialectic" suggests a closed system of truth. It may display a way of thinking that presupposes a magic bullet of understanding and a fixed totality of thought that is in fact antidialectical. See, for example, Fredric Jameson, Valences of the Dialectic 5 (2010). Having said that, the term is an adequate descriptor for a journeyman like me trying to understand Marx's method and apply it as a method in concrete circumstances to gain a deeper understanding of the specific under examination and the system of which it is a part.

69 V I Lenin, On the Question of Dialectics, 38 Collected Works 359 (2d ed., Progress Publishers 1965). 
low the world whole at one sitting than our stomachs." ${ }^{70}$ Partly, it is done to reveal the essence hidden by the appearance.

This general approach emphasizing totality, contradiction, and change, too, is reflected in John Rees' discussion of the dialectic. He said that its general form "... is an internally contradictory totality in a process of constant change." 71 On this view, there are three major elements or principles of the dialectic-totality, change, and contradiction. ${ }^{72}$ For Rees, totality expresses interconnectedness, the idea and the fact that what appear to be separate are, in fact, related..$^{73}$ Lukács made clear that the idea of totality is, or should be, at the heart of Marxist thought and analysis. As he said, "it is not the primacy of economic motives in historical explanation that constitutes the decisive difference between Marxism and bourgeois thought, but the point of view of totality." ${ }^{74}$ That totality is society. ${ }^{75}$

Under capitalism, the producer is separated from the productive process as a whole. Workers are atomized and individuated, divorced from the wider system of which they are an integral part. ${ }^{76}$ Most academics and other thinkers silo their field of study-for example, tax law-treating it as a concrete whole divorced from wider forces and separate from the idea that it is an integral part linked and in conflict with other concrete wholes. Despite the division of labor and, with it, of most thinking about particular subjects, there are in fact no separate categories of thought. Lukács again said:

Marxism, however, simultaneously raises and reduces all specializations to the level of aspects in a dialectical process. This is not to deny that the process of abstraction and, hence, the isolation of the elements and concepts in the special disciplines and whole areas of study is of the very essence of science. But what is decisive is whether this process of isolation is a means towards understanding the whole and whether it is integrated within the context it presupposes and requires, or whether the abstract knowledge of an isolated fragment retains its 'autonomy' and becomes an end in itself. In the last analysis, Marxism does not acknowledge the existence of independent sciences of law, economics or history, etc. There is nothing but a single, unified-dialectical and historical—science of the evolution of society as a totality. ${ }^{77}$

70 Ollman, supra note 10, at 60.

${ }_{71}$ Rees, supra note 3, at 7.

72 Id. at 5.

73 Id.

74 Lukács, supra note 32, at 27.

75 Id. at 28.

76 Id. at 27.

77 Id. at 28 . 
Alternatively, as Alfredo Saad-Filho said, "the capitalist economy...is integral and whole, and...this organic system of mutually conditioning things is determining with regards to its parts, or moments." 78 This expresses a deeper understanding of society-that it is a totality, not a set of separate isolated units or sectors. Each sector is in creative conflict with the other parts, fighting to reflect their own seeming interests in the context of the totality, that is, the capitalist system. The whole is greater than its parts, parts that contradict and conflict. It is this ongoing conflict that drives change. The major contradiction and conflict (sometimes hidden, sometimes open $)^{79}$ is, under capitalism, that between capital and labor. Tax reflects and reinforces that division and, in turn, reflects and reinforces the state of struggle between the two.

So it is with any attempt to understand tax-understanding the tax system and its specifics as part of a whole, but a whole in the process of constant change in which the individual parts conflict and battle each other to produce change. Not only that, it is about abstracting from the specifics to better understand them. Totality, contradiction, and change sums up the process. ${ }^{80}$ Tax and tax reform are one part of a wider process of capitalist accumulation, both encouraging and feeding off that process. ${ }^{81}$ However, tax is also something more than this. Tax helps mediate the relationship between labor and capital but introduces or, rather, is introduced by a new layer of complexity-the state.

The contradiction at the heart of capitalism is that between capital and labor, or as Engels put it: "The contradiction between socialized production and capitalistic appropriation manifested itself as the antagonism of proletariat and bourgeoisie." ${ }^{2}$ I would go further than Engels. The very fact of division between one group who sell their labor power and another who live off that labor is itself the contradiction, of which the reality of socialized production and capitalist appropriation is an expression under capitalism. The antagonism between capital and labor, the class struggle, ${ }^{83}$ is the driving force of capitalist history ${ }^{84}$ and the key to understanding the future developments within capitalism but also breaking out of it, the synthesis that is socialism. The two classes stand "in constant opposition to each other, [carrying] on an uninterrupted, now hidden, now open fight ..." ${ }^{85}$ It is this battle that expresses itself in many forms of change. Thus

78 Alfredo Saad-Filho, The Value of Marx: Political Economy for Contemporary CAPitalism 9 (2002).

79 MARX \& Engels, supra note 26, at 36.

80 Rees, supra note 3, at 7.

81 Chris Harman, Zombie Capitalism: The global Crisis and the Relevance of Marx 113115 (2009).

82 Friedrich Engels, Socialism: Utopian and Scientific, in The MarX-Engels Reader 705 (Robert Tucker ed., 3d ed. 1982).

83 Or the lack of it by the working class and, hence, dominance of the ruling class.

84 MARX \& ENGELS, supra note 26, at 1.

85 Id. 
neoliberal policy will produce a set of policy prescriptions to address the tendency of the rate of profit to fall, whether it be a longer working day or improved labor productivity, or reducing real wages and undermining work conditions, or cutting taxes. So the surface expression of this aspect of class struggle might be fought out over attempts to cut the social wage, disproportionate tax cuts for the rich and capital, or the reality or perception of increasing tax burdens on workers.

In Australia, industrial action-the open fight by workers in the battle between capital and labor-has been mainly hidden for many years. ${ }^{86}$ This class peace, with strike days per thousand employees lost now standing at only a few percent of the late 1960s and early 1970s, what Bramble calls the ebb tide, ${ }^{87}$ has had an adverse impact on the material and political life of the working class and on tax policy. This is now a seemingly unchallenged neoliberal paradise, at least in theory and for the purposes of reviews, but one in which the plans for reform meet the dead hand of the past (the current system) and a deep working class suspicion of tax change that may impact adversely on them. As Marx put it, with just a little bit of tinkering from me: "The tradition of all dead [tax] generations weighs like a nightmare on the brains of the living." 88

Bernard Keane in Crikey ${ }^{89}$ had compiled a graph of the decline in strike levels since the first few years of the Accord from Australian Bureau of Statistics (ABS) data. It shows a massive decline in strikes and other open expressions of working class fight-back.

86 Tom Bramble \& Rick Kuhn, Labor’s Conflict: Big Business, Workers and the PoliTICS OF Class 170 (2011).

87 Bramble, supra note 41, at 4. For a very good graph highlighting the huge decline in strikes from the flood of the mid-1970s to the ebb tide up to 2007, see Bramble at 7. Australian Bureau of Statistics (ABS) figures for the period 2008-2013 show a further overall decline, with some slight pick-up in 2012/2013 because of big strikes in the construction industry and among teachers and nurses-but still, in the context of the historic levels of strikes on an average, very very low: http://abs.gov.au/ausstats/abs@.nsf/mf/6321.0.55.001?OpenDocument (last visited Jan. 7, 2016). Figures from 1960 to 2010 show the massive nadir in working class struggle today and for the last few decades, compared with the zenith of the mid-1970s; Australian Bureau of Statistics, Year Book Australia 2012 available at http://www.abs.gov.au/ausstats/ abs@.nsf/Lookup/by\%20Subject/1301.0 2012 Main\%20Features Workplace\%20 relations $\sim 300$ (last visited Jan. 7, 2016). A precipitous decline began with the election of the Hawke Labor Government in 1983 and was a result of the wage restraining Accord between the government and union leaders. Union membership also plummeted accordingly. $I d$, at 313 .

88 Marx, supra note 29, at 13.

89 Bernard Keane, How the FWA Was a Miserable Failure - at Justifying Business Hysteria, CRIKeY, Mar. 14, 2014 available at http://www.crikey.com.au/2014/03/14/howthe-fwa-was-a-miserable-failure-at-justifying-business-hysteria (last visited Jan. 7, 2016). 


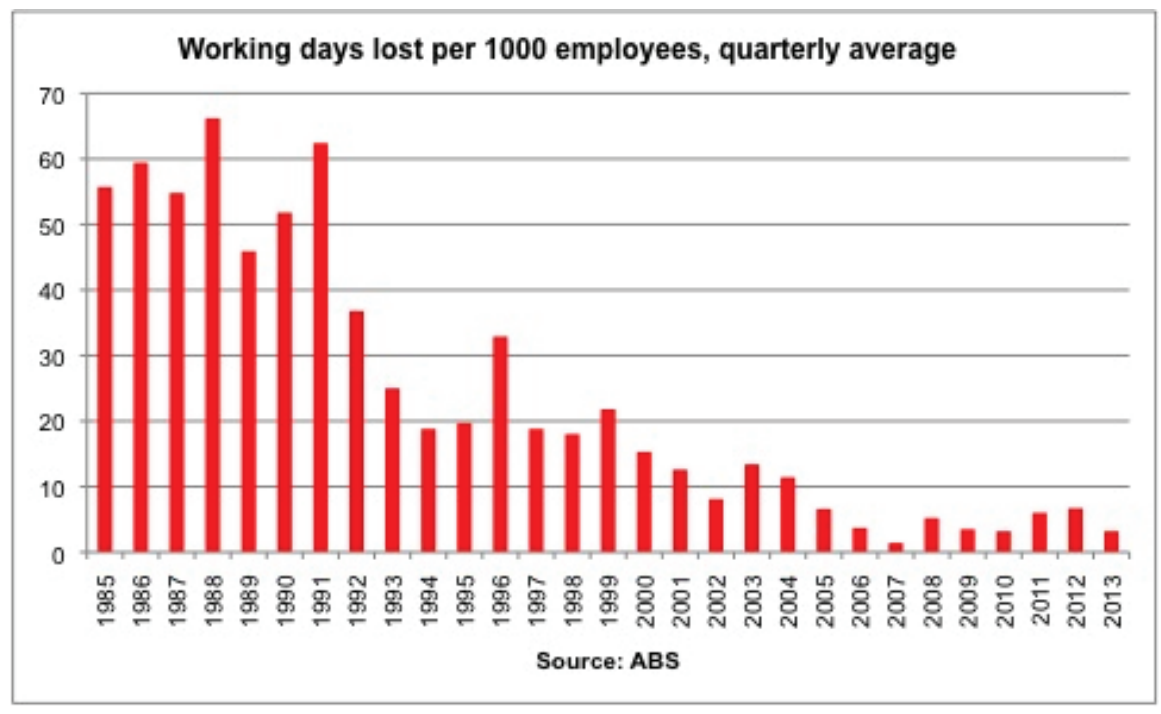

Class antagonisms also play an important, if often indirect, part in the design and ongoing relevance of tax systems and shifting tax bases, tax policy direction. The level of class struggle impacts on the general political climate, and this influences all politicians, including politicians of the reformist left and their approach to tax. All, of course, interact and struggle with each other as part of the bubbling mud pools of tax change. Now, of course, the interplay between capital accumulation, profit rates, and taxes is vital to understanding the role tax change plays in propping up the capitalist system by, for example, reducing the tax burden on the reapers of profit. In other words, it acts as a countervailing action to the tendency of the rate of profit to fall. ${ }^{90}$

We can see the contradiction between capital and labor playing out in the media at the moment with calls for major reform based on the Henry Tax Review recommendations and the head of that group, Ken Henry, warning of a tax crisis in the near future if reform is not pushed more forcefully. ${ }^{91}$ The release in 2015 of Re:think, the Federal Government's White Paper on taxation, prompted further agitation from some politicians, interest groups, and commentators for tax reform..${ }^{92}$ Much of the business

90 Marx, supra note 50, at 279 et seq.

91 Anderson, supra note 5.

92 The Australian Government, The Treasury, Re:think - Tax Discussion Paper (2015) available at http://bettertax.gov.au/files/2015/03/TWP_combined-online.pdf (last visited Jan. 7, 2016) [hereinafter RE:THINK]. For other media commentary, sparked in part by the release of the tax white paper, see, for example, Helen Hodgson, Government calls for tax rethink, but reform answers abound THE CONVERSATION Mar. 30, 2015 available at https://theconversation.com/government-calls-for-tax-rethink-but- 
reform agenda focuses on expanding the base of Australia's value-added tax, the Goods and Services Tax (GST), to include fresh food and spending on health and education and increasing the rate from 10 to 15 percent and cutting income tax, in particular the company tax rate, although the Labor Opposition has shifted the debate with its proposals to allow negative gearing of rental properties only on new housing and to reduce the capital gains tax concession, while the Government has taken a GST increase off the table in the run up to the election due some time in $2016 .^{93}$

Underlying changes in society can force tax changes. Changes within Australian and global capitalism (recognizing that Australian capitalism is part of global capitalism and becoming more and more integrated into the global system), against a background of an almost complete lack of industrial action by workers, are worthwhile areas for investigation to understand tax reform and the push for tax reforms in Australia.

reform-answers-abound-39436 (last visited Jan. 6, 2016). Hodgson is critical of the fact RE:ThinK is a series of questions about tax reform, not answers. The Tax Green Paper, after a period of consultation sparked by RE:THINK, was to provide those answers but the ascension of Malcom Turnbull to the prime ministership in September 2015 appears to have delayed the release of that Tax Green Paper and to have shifted its focus. See Mark Hawthorne, Malcolm Turnbull halts tax white paper process in major "reset" SYdney Morning Herald Sept. 23, 2015 available at http://www.smh. com.au/business/the-economy/malcolm-turnbull-halts-tax-white-paper-in-major-reset-20150923-gjstsm.html (last visited Jan. 6, 2016).

93 Roger Brake from the Treasury Revenue Group has listed some of the key issues arising in the discussion of tax reform, including personal and company income tax cuts, reducing the superannuation and capital gains tax concessions, addressing in some way the negative gearing of rental properties, and broadening the Goods and Services Tax (consumption tax) base and/or increasing the rate. See Roger Brake, The Treasury, An Inside Perspective on the Tax White Paper (2015) (speech at the VIC $3^{\text {rd }}$ Annual Tax Forum, October 8, 2015), http://www.treasury.gov.au/PublicationsAndMedia/Speeches/2015/ An-inside-perspective-on-the-Tax-White-Paper (last visited Jan. 6, 2016). However the Prime Minister Mr Turnbull has since announced that the government will not be taking a GST increase to the 2016 election, in my view for fear of losing a large number of votes or possibly even the election itself. Stephanie Anderson and Eliza Borrello, GST increase not being taken to election by Malcolm Turnbull ABC NEWS Feb. 16, 2016, available at http://www.abc.net.au/news/2016-02-16/turnbull-rules-out-gst-changeelection-policy/7172294 (last visited Mar. 5, 2016).

The Business Council of Australia, recognising the opposition to GST and other changes that might be seen as unfair, has recently put out a discussion paper on tax reform suggesting their proposing be phased in over time, with the company tax cuts first priority and the GST changes pushed back to 2025. Realising Our Full Potential: Tax Directions for a Transitioning Economy BCA Mar. 8, 2016, available at http://www.bca.com.au/publications/realising-our-potential-tax-directions-for-a-transitioning-economy (last visited Mar. 13, 2016).

Details of the Labor Party's negative gearing and capital gains tax proposals can be found here. Australian Labor Party, Positive plan to help housing affordability, available at http://www.alp.org.au/negativegearing (last visited Mar. 6, 2016). 
Dialectical thinking can help us in that understanding. Some readers might have read about the "three laws of the dialectic." These "laws," drawn from Engels, are "the unity of opposites, the transformation of quantity into quality, and the negation of the negation." 94 Essentially, the unity of opposites is one way of describing contradiction. Quantity into quality expresses the idea that a gradual change in the relationship of the contradictory forces can suddenly produce rapid and complete change. The negation of the negation highlights the fact that the old is contained in the new but transformed by the process of rapid change into something completely different. ${ }^{95}$ These "laws" are examples of a "way in which dialectical development can take place" 96 but are not the only way this can happen and are not, in fact, laws themselves. While they are useful examples of dialectical change, we should be very wary of applying them like judges at a criminal trial.

While we tax experts may look deeply into the eyes of the policy makers and parliamentarians-invariably not the same people-to discern meaning, or even investigate the underworld of structural drivers, what we generally don't do is posit tax and tax policy debates and discussions in the context of a specific time in history where production is organized (fleetingly as it happens in the grand scheme of human development $)^{97}$ to make profit and reinvest that profit in yet more profitable activities, that is, to accumulate. ${ }^{98}$ In short, we tend to divorce tax, tax law, tax policy, and tax reform from capitalism, from the accumulation process and the role tax, tax law, policy, administration, and reform play in the capitalist system and the interactions between the parts and the totality, the multilevel interactions, between tax and capitalism. All the dirty windows are waiting to be cleaned and then opened. We just don't yet know how to find the ladders to help us climb to the second floor to clean and peer in. The concepts of appearance and reality are a start.

\section{E. Appearance and Reality}

Ollman relays a wonderful story from mythology 99 that Marx used. ${ }^{100}$ Cacus, a clever old man-demon, lived in a cave. He came out at night to steal oxen from nearby villages, driving them backwards into his cave so that when the villagers came looking for their stock, all they found were footprints leading

94 Rees, supra note 3, at 8.

95 Id, at 9.

96 Id, at 8-9.

97 Joseph M Gillman, The Falling Rate of Profit 1 (1957).

98 MARX, supra note 25, at 557. As Marx put it, "Accumulate, accumulate! That is Moses and the prophets."

99 Ollman, supra note 10 , at 12-13.

100 Karl Marx, Theories of Surplus Value Part III 536-537 (Progress Publishers, 1975). 
from the cave: thus the oxen apparently disappeared in the middle of a field. Our task is to work back from the footprints of profit and wages and their taxation to the cave of surplus value.

In other words, we need to break through the surface phenomena to understand the deep structures we are dealing with. Whether we acknowledge it or not, we are social scientists in the field of tax. As Hobsbawm put it, drawing on Engels, "[t]he good social scientist [can] only be a person free from the illusions of bourgeois society." ${ }^{101}$ Because capitalism is still in business, Marxism is and must be, too. ${ }^{102}$ Doing this is not to be doctrinaire and not to demand that readers kneel down before "the truth." ${ }^{103}$ It is to "develop new principles for the world out of the world's own principles ... We merely show the world what it is fighting for and consciousness is something that it has to acquire, even it does not want to." 104

At one level, most readers-I hope-can accept that to understand tax, you need to understand it in its political, social, and economic contexts. That trite statement contains a real kernel of truth, one that political economists and tax academics like me can build on. As Marx put it: "If the essence and appearance of things directly coincided, all science would be superfluous." 105 This is as true of the social sciences (including tax, tax reform, and tax law) as it is of the natural sciences. Because capitalism is so complex, we can end up accepting its surface appearances as the only reality or we can simplify that complexity to such an extent we lose the truth contained in the complexity. ${ }^{106}$ To avoid these pitfalls, we can adopt Marx's method "to abstract from the misleading appearance of things." ${ }^{107}$ What Marx seeks to do is "understand the most basic processes in capitalism and then to reconstruct ever more complex aspects of the system in his theory. Once this is done, it becomes clear how the 'basic laws of motion' generate the complicated surface appearances." 108

That is true, too, of tax. You cannot understand tax and tax reform divorced from the society in which it exists. Society is split into classes. One owns the means of production and the other sells its labor power to survive. Through its labor, one produces surplus value, the other expropriates or obtains that surplus or part of it. ${ }^{109}$

101 Eric Hobsbawm, How to Change the World: Tales of MarX and MarXism 95 (2011).

102 Terry Eagleton, Why Marx was Right 2 (2011).

${ }^{103}$ Karl Marx, Letter to Arnold Ruge, September 1843 quoted in Kieran Allen, Marx and the Alternative to Capitalism (Pluto Press, 2011) 13 and available at http://www. marxists.org/archive/marx/works/1843/letters/43_09.htm (last visited Jan. 7, 2016).

${ }_{104} I d$.

${ }^{105}$ MARX, supra note 50, at 817.

106 Joseph Choonara, Unravelling Capitalism: A Guide to Marxist Political Economy 16 (2009).

${ }_{107} I d$. at 17.

${ }_{108}$ Id.

${ }^{109}$ Harman supra note 81, at 28-33. 
"Objective" truth does not just arise; it is not discovered like gold. ${ }^{110}$ Marx said "[t]he question whether objective truth can be attributed to human thinking is not a question of theory but is a practical question. Man must prove the truth, i.e. the reality and the power, the 'this-worldliness' of his thinking in practice." 111 That practice is, as Paul D'Amato argued, class struggle. ${ }^{112}$ Thus, we might argue that the objective truth of progressive tax as part of a wider attack on growing inequality ${ }^{113}$ can be won through class struggle. In the words of the great trade union philosophers, "If you don't fight, you lose." 114

However, in understanding the reality of tax and exploitation, tax and the state, tax, and capitalism, it becomes clear that progressive victories may, at best, be temporary and the daily grind of the needs of capital for profit and accumulation undermine or threaten to undermine every ounce of social progress the working class has won. Winding back or destroying the welfare state in Europe is but one current example. ${ }^{115}$ So, too, is the extension of the working day in many countries of the developed world, including Australia. ${ }^{116}$ Lengthening the working day extracts more surplus value out of workers. It is one response to the reassertion since the late 1960s and early 1970 s in most developed capitalist countries of the tendency of the rate of profit to fall. Thus unpaid overtime-a gift to the capitalist class-is now estimated to total about $\$ 110$ billion a year in Australia, ${ }^{117}$ or about $7 \%$ of GDP. As one senior trade union official wryly remarked at a May Day celebration a few years ago, maybe the trade union movement needs to begin a campaign for the eight-hour day again. ${ }^{118}$ The extension of the working day, much of it unpaid, ${ }^{119}$ is an attempt by the ruling class to increase the absolute surplus value it can expropriate from workers. ${ }^{120}$

${ }^{110}$ Unlike, evidently, the 'correct' case decision, according to rule of law proponents.

111 Karl Marx, Theses on Feuerbach, in Marx, Engels Selected Works 28 (Lawrence \& Wishart 1968).

112 Paul D'Amato, The Powerlessness of Anti-power: Review of "Change the World Without Taking Power" by John Holloway, 27 InT'L Socialist Rev. (2003) available at http://www.isreview.org/issues/27/holloway.shtml (last visited Jan. 7, 2016). I am indebted to D'Amato, having drawn heavily on his ideas in this paragraph.

${ }_{113}$ Leigh supra note 15; Stiglitz, supra note 15.

114 This was, and is, one of the slogans of a militant Australian trade union, the Builders Labourers Federation. See Liz Ross, Dare to Struggle, Dare to Win! (2004).

115 John Passant, Lessons from the Recent Resource Rent Experience in Australia, 10 CANBERRA L. REv. 159, 178 (2011) available at http://www.austlii.edu.au/au/journals/CanLawRw/2011/25.html (last visited Jan. 7, 2016).

116 Brigid van Wanrooy, A Desire for 9 to 5: Australians' Preference for a Standard Working Week, 17 LABOUR \& Industry 71, 73-74 (2007).

117 David Baker et al., Walking the Tightrope: Have Australians Achieved Work/Life BALANCE? 1 (2014).

118 This was a personal observation on her part. She spoke to me at that rally.

119 van Wanrooy, supra note 116, at 74 .

${ }^{120}$ MARX, supra note 25, at 645. 
One final point. The state levies tax. Rather than some neutral body overseeing society, the capitalist state is a creature of the capitalist system. ${ }^{121}$ This is not the place to go into the debates about the state other than to adopt the view of "the relative autonomy of the state" 122 in the sense that it can act independently of the interests of particular sections of capital or particular capitalists but that its ultimate existence depends on the continuation of the extraction of surplus value from workers in the productive sector of society. ${ }^{123}$ As such, tax cannot unduly interfere with or challenge that exploitative process. ${ }^{124}$

The state is one of the band of hostile brothers of capital, united in exploiting workers but fighting among themselves for a greater share of surplus value.

\section{TAX AND The Dialectic}

The rise of capitalism in England and its wars with revolutionary France saw income tax introduced as a temporary measure until the wars ended and the tax was repealed in $1816 .^{125}$ In this sense, income tax is both a creature and creation of the capitalist state. However (and leaving aside discussion of the fact that the income tax did not at this stage apply to the working class), income tax can only arise in a society in which there is generalized income earning. Such generalized income earning, the first in human history, is one hallmark of capitalism, a system of commodity production and exchange to make profit to reinvest to make more profit through the next round of production and exchange. The possibility of income tax can only arise in the context of the generation of income-in other words, for capital in the process of commodity exchange and for labor through the sale of labor power, itself a form of exchange.

${ }^{121}$ Chris Harman, The State and Capitalism Today 2 International Socialism Journal 3 (Ser. No. 2, 1991) available at https://www.marxists.org/archive/harman/1991/xx/ statcap.htm (last visited Jan. 7, 2016).

${ }^{122}$ Id. See also Harman, supra note 81, at 111.

${ }^{123}$ This "rule for capital not capitalists" role often fell to Labor or social democratic parties because in the past their social base was the trade union or working class movement, not the corridors of capital. See Passant, supra note 115, at 174 et seq. However, as the experience of the Gillard Labor Government and the Minerals Resource Rent Tax suggests, the changing nature of the ALP from a capitalist workers' party to a CAPITALIST workers' party may mean that role is no longer one it can undertake. See Passant, infra note 129.

${ }^{124}$ Harman supra note 81, at 113-15.

${ }^{125}$ Martin Daunton, Trusting Leviathan: the Politics of Taxation in Britain 17991914, 24 (2007). 
It is not capital that imposes taxes. It is the state, a state dependent on the capital accumulation process for its existence and survival. This does not make the state a mere instrument of capital. Nor is the modern state in advanced capitalist countries such as Australia just or only "the executive committee for managing the common affairs of the bourgeoisie." 126 The structural dependence of the state on capital ${ }^{127}$ limits the choices governments can make. This does not mean that they don't have choices. It does mean that they are neither autonomous nor straitened. Governments are relatively autonomous within the bounds imposed by capital accumulation. ${ }^{128}$

For example, the state can impose solutions on capitalism for the benefit or survival of the system as a whole and at the expense of particular sections of capital if needed. In Australia, this role has traditionally fallen to the Labor Party because of its structural links to the trade union bureaucracy and arm's length distance from capital. Those days appear to be well in the past, as the failure of Labor to impose a Resource Super Profits Tax and only being able to pass a watered down version in the form of the Minerals Resource Rent Tax, a tax designed by the three big multinational mining companies in Australia, shows. ${ }^{129}$

\section{A. The Establishment of Capitalism in Australia AND THE IMPOSITION OF INCOME TAX}

Before Federation in 1901, and after the British invasion in $1788^{130}$ and the ongoing genocide of Aboriginal people, ${ }^{131}$ some of the Australian colonies had begun the move from regressive and inequitable taxes to progressive ones on land and income. ${ }^{132}$ This change reflected the long, slow process of establishing capitalism in Australia, moving initially from a forced la-

126 MARX \& Engels, supra note 26, at 1.

127 Adam Przeworski \& Michael Wallerstein, Structural Dependence of the State on Capital, 82 Am. Pol. Scr. Rev. 11, 12 et seq. (1988).

128 Harman, supra note 81.

129 John Passant, The Minerals Resource Rent Tax: The Australian Labor Party and the Continuity of Change, 27 Aсcт. Res. J. 19 (2014).

${ }^{130}$ Henry Reynolds, The Other Side of the Frontier: Aboriginal Resistance to the European Invasion of Australia (1981); Colin Tatz, Confronting Australian genocide, 25 Aboriginal Hist. 16, 23 (2001).

131 Colin Tatz, Genocide in Australia, 1 J. Genocide Res. 31 (1999); Colin Tatz, supra note 130, at 16; A. D. Moses, Genocide and Settler Society in Australian History, in GeNOciDE and Settler Society (A. D. Moses ed., 2005). For an example of the ongoing nature of the genocide, see Human Rights and Equal Opportunity Commission (Australia), Bringing them Home: Report of the National Inquiry into the Separation of Aboriginal and Torres Strait Islander Children from Their Families 236 (1997).

132 Sam Reinhardt \& Lee Steel, A Brief History of Australia's Tax System (2006) available at http://archive.treasury.gov.au/documents/1156/HTML/docshell.asp?URL=01_ Brief_History.asp (last visited Jan. 7, 2016). 
bor economy to a free labor one and with it the ongoing development of agricultural, industrial, retail, and finance capital Australia, or as Hillier and O'Lincoln put it, by 1820, a "state-run prison with capitalist features was transforming itself into a full-blown capitalist society in eastern Australia." 133 One consequence of this was the development of a working class who because of the nature of the capital/labor relationship wanted (and still want) social democratic gains appropriate for their times, often couched in terms of some variant on "fairness." Progressive taxation, especially when the working class is taxed, is one outcome of this systemic social democratic desire. In addition, the state met the needs of capital in an admittedly rudimentary way for an educated workforce, one fit enough to work profitably for the capitalist class, and in more systematic fashion to fund a police force and army to control rowdy workers and engage in imperialist adventures with the mother country from 1885 on in places such as the Sudan, South Africa, and then Europe.

By the time of Federation, many of the States had income taxes, but they were levied on different definitions of taxable income and at different rates. ${ }^{134}$ Some applied only to residents and others taxed on a source basis. ${ }^{135}$ Funding the First World War drove the Labor Government of Billy Hughes to introduce a Federal income tax in 1916. ${ }^{136}$ From then until 1942, there were both federal and state income taxes. The need to fund the war effort in the Second World War, the ongoing centralization of power in the Federal Government, and the inequities inherent in a dual state and Commonwealth income tax saw the Federal Government impose a uniform income tax in 1942. While this, on paper, allowed States to impose income tax, they would lose all Commonwealth grants if they did so. From then on, the income tax effectively became the sole Commonwealth responsibility. ${ }^{137}$

This confirmed the process of centralization of power into the hands of the Federal Government that was occurring within Australia from the time of Federation and which was boosted by the Second World War. ${ }^{138}$ This centralization was further reinforced by the demands for and expansion of the welfare state after World War II. So too was the expansion of the income system. While the original Federal Income Tax applied only to high income earners, over time the tax expanded its reach to include the wages of ordinary working class taxpayers. ${ }^{139}$

${ }^{133}$ Ben Hillier \& Tom O'Lincoln, Five Hundred Lashes and Double Irons: The Origins of Australian Capitalism, 5 MarXIst LeFt Review (2013) available at http://marxistleftreview.org/index.php?option=com_content\&view=article\&id=89:five-hundred-lashes-and-double-irons-the-origins-of-australian-capitalism\&catid=42:number-5-summer-2013\&Itemid=81 (last visited Jan. 7, 2016).

${ }^{134}$ Reinhardt \& Steel, supra note 132.

${ }_{135} \mathrm{Id}$.

${ }^{136} I d$.

${ }_{137} I d$.

${ }_{138} I d$.

${ }_{139} I d$. 
Wages are the market price for the sale of a worker's labor power, their ability to work. That labor power is itself valued by reference to the socially necessary labor time that goes in to the commodity. In short, it is the amount need to reinvigorate the worker for work the next day and into the future, to allow him or her enough to raise a family as the next generation of workers and to provide for some historically specific expenses such as a few beers or wines on Friday night watching the footy. ${ }^{140}$

Wages will fluctuate around this value level, depending on the level of class struggle. This means that after tax wages, in times of relative economic prosperity will not be below their value. However, it also means that income tax can, at times, cut real wages to below their value. So a fight for a living wage can be a fight to overcome the desire and often reality of capital to pay workers the minimum they can to maximize their profits.

However, it can also be a fight over the ability of the state to tax workers' earnings to avoid their after tax real wage falling below the level of their value. It, too, can be a fight over the amount of tax imposed on capital, although arguably this can be recouped in the market assuming that capital can increase prices to adjust for taxes. This may not always be the case, especially if the products the particular capitalist produces compete in offshore markets where similar taxes or levels of tax do not exist.

More importantly, the bourgeoisie or sections of it may demand cuts in taxes on capital in response to international competition or more fundamentally as one of the number of counteracting tendencies or countervailing methods to address the systemic tendency of profit rates to fall. ${ }^{141}$ This could, for example, involve cuts to company taxes to "remain competitive" in line with overseas trends or cuts in government spending on the social wage or a combination of both.

There may be a struggle over the social wage where the state extracts both income tax from workers and redistributes some of that to those workers in the form of public services such as education, health, transport, unemployment benefits, and other social security payments. The provision of such social services may be cost-effective for the State in creating a fit and educated workforce (and, hence, more exploitable workers), but it may rob certain spheres of activity such as public health and education from commodification and, hence, profit making for private capital. ${ }^{142}$ It also imposes a burden on the State to fund such spending and on labor and capital, depending on who bears the burden of the taxes imposed, and if the decline in relative surplus value from which to extract tax is systemic,

${ }^{140}$ MARX, supra note 25, at 167-68.

${ }^{141}$ For a discussion of the Law, see III Karl Marx, Capital 210 et seq (Progress Publishers, 1974); see also id. at 222 et seq. for a discussion of the counteracting tendencies.

142 The long slow march-or perhaps zigzag-to private education and health care in Australia has been ongoing since the election of the Hawke Labor Government in 1983. The links Labor had with the union movement enabled it, for example, to introduce a "pay later" scheme for higher education in 1988/1989. 
then it creates further pressure for cutting taxes on income that comes out of that pool of surplus value.

\section{B. Class Antagonisms in the Tax System}

Clearly, there are class antagonisms in tax systems. Tax issues from 1763 onwards were one of the sparks for the American Revolution and tax lit the bourgeois revolution in France in 1789. Even in Australia, tax (in the form of mining licenses) was at the heart of the Eureka Rebellion in 1854.They are specific examples.

However, it was not tax that prompted the working class revolution in Russia in 1917 or the many outbreaks of revolution across Europe during and after World War I. It was privation, poverty, lack of democracy, and slaughter. It wasn't tax that saw Chinese workers revolt in 1926, nor was it tax that saw Hungarian workers rise up in 1956 against the Stalinist dictatorship. It wasn't tax that fueled the workers rising up during the Iranian revolution of 1978-1979. Tax wasn't at the heart of the working class and other agitations against Stalinism in Poland in 1956, 1970, or1980-1981. It wasn't tax that was at the heart of the overthrow of the Stalinist regimes in Russia and Eastern Europe in 1989-1991. Tax, however, was (and remains) part of the system of exploitation and oppression, including war and privation, which saw workers in these disparate countries, across many generations, revolt.

While tax was a barrier to capitalist development in France in the years preceding $1789,{ }^{143}$ it is not a barrier to the development of a participatory socialist society. ${ }^{144}$ The working class exists as an entity with the potentiality to create that new society where production is organized democratically to satisfy human need rather than to make profit to be reinvested again and again in the pursuit of more profit. Income tax can, depending on the specifics of the circumstances of each particular country, be one of the mechanisms for a reduction in working-class living standards. However, paradoxically, cutting taxes on workers may not improve living standards if it is accompanied by cuts to or abolition of the social wage. The increased costs of privatized education or health could outweigh the improved after tax wage as a consequence of tax cuts on wages. The combativity of the working class, or lack of it, and the level of relative surplus value would be

${ }^{143}$ Leonard J. Hochberg, Reconciling History with Sociology? Strategies of Inquiry in Tocqueville's Democracy in America and The Old Regime and the French Revolution, 7 J. of Classical Soc. 23, 41 (2007); II Alexis de Tocqueville, The Old Regime and the Revolution, 5 (2001); Keith Baker et al., The Old Regime and the French RevoluTION (1987).

${ }^{144}$ For a good discussion of the history of democracy, including socialist participatory democracy, see Brian Roper, The History of Democracy: A MarXist Interpretation (2013). 
important contributors to any struggle and likelihood of success over tax and social services.

There is also a temporal dimension in tax. Bracket creep, when increases in wage move workers into higher marginal tax rates, is an important part of any slow, ongoing increased taxation on workers and possibly, depending on the level of wage increases, decreasing or helping to decrease after tax living standards, too. The introduction of the GST in Australia from 1 July, 2000, is a case in point. It was accompanied by income tax cuts whose value was eroded over time through bracket creep. One estimate is that by $2005 / 2006$, bracket creep had clawed back $\$ 3.8$ billion of the GST tax cuts, ${ }^{145}$ tax cuts themselves at least in part funded by bracket creep in the years before the introduction of the GST. Even a superficial understanding of tax can then show that all is not as it seems. Tax cuts are eroded over time through tax creep. As workers' wages increase, their average tax rate increases. This is so irrespective of whether they actually move into a higher tax bracket because the increased income is taxed in the highest marginal rate, increasing the government's average tax take from each worker. Leaving aside these surface phenomena, a tax system taxing income reflects what is happening on the surface in the realm of exchange. While this surface is a reality and impacts on the real lives and livelihoods and living standards of workers, it hides and obfuscates a deeper reality.

\section{I'M WALKING BACKWARDS FOR CACUS}

Income tax in Australia is imposed on "taxable income": assessable income less allowable deductions. Income, whatever form it takes, is a given. Wages, dividends, interest, rent, and profits, for example, are all specific examples of income that is assessable income and often will also be taxable income. Income is a generic term that captures different forms of income and does not ask from whence this magical item arises. The answer seems self-evident. Wages come from labor. Profits arise from business, or capital and activity. Interest comes from invested money. Rent is the product of land. Dividends flow from shares.

As mentioned previously, this reflects in part what Marx called the Holy Trinity approach of Adam Smith. In short, the income tax system is based on what Marx describes as the (apparent) Trinity Formula of capitalprofit, labor-wages, and land-rent. The income tax system is an outgrowth

145 Thus Hielke Buddelmeyer et al. said, "This $\$ 3.8$ billion is the dollar amount of bracket creep, expressed in first quarter 2004 dollars, and represents what it would cost to compensate the Australian tax payers for the extra amount of tax they would pay in 2005/06 as a result of inflation as measured by the CPI since 2000/2001." See HielKE Buddelmeyer et al., Bracket Creep, Effective Marginal Tax Rates and Alternative TAX PACKAgES available at https://www.melbourneinstitute.com/downloads/labour/ WebReport.pdf (last visited Jan. 7, 2016). 
of an economic system that fetishizes commodities and sees relationships between people as relationships between things. It not only hides the exploitation of workers. It misallocates the creation of profit, interest, rent, and dividends-specific examples of the general category of surplus value-in the hands of capital rather than labor. It views workers as being rewarded for their labor rather than the reality of the reward being for their ability to labor and taxes them accordingly.

What the tax system deals with is the phenomena arising in the distribution of surplus value, not its production. As Paul Mattick puts it, " $[t]$ axes are a part of realized income through market transactions..." ${ }^{446}$ While production and circulation "intertwine and intermingle continually and thereby adulterate their typical distinctive features," 147 profit, a specific and concrete market form of the more general and abstract category of surplus value, appears to the capitalist and indeed to the rest of society, as the real value and to arise in circulation, rather than production. Further, profit appears to arise from total capital invested (i.e., from the cost of machinery, factories, land, as well as labor) rather than from workers, or what Marx calls variable capital. These surface realities, these appearances, find expression in the tax system in the form of the general taxpayer, an abstract individual or concept divorced from his or her role in society as in the main either capitalist or wage laborer. They also find expression in the key concept of assessable income in our income tax system, an abstraction hiding, as it does the reality of the source of that income in the form of profits, interest and the like, and wages. Yet we are walking backwards and the Cacus capitalist is stealing the value workers create. Tax helps steer this backward walk.

The income tax system involves itself with the money that arises from the exchange of commodities and the money value of labor, in other words, the price received for the sale of goods and services in the market place and of labor power in the job market, not recognizing the social relations that these represent. In this way, the income tax system reflects capitalism and reinforces the mystique of capitalism. As Marx said: "The mystification here arises from the fact that a social relation appears in the form of a thing." 148 The "thing" here appears on the one hand as the commodities produced and on the other as the money form of capital or labor, in turn profit, interest, rent, or wages. The social relations are reified in both production and exchange that although viewed as separate are actually a unity or processes that describe capitalism. Marx again stated:

\footnotetext{
146 Paul Mattick, Monopoly Capital, in Anti-BolsheviK Capitalism (1978) available at https://www.marxists.org/archive/mattick-paul/1966/monopoly-capital.htm (last visited Jan. 7, 2016).

${ }^{147}$ MarX, supra note 50, at 44.

${ }^{148}$ Karl Marx, Theories of Surplus Value Part I 313 (Progress Publishers 1975).
} 
A commodity is therefore a mysterious thing, simply because in it the social character of men's labor appears to them as an objective character stamped upon the product of that labor; because the relation of the producers to the sum total of their own labor is presented to them as a social relation existing not between themselves, but between the products of their labor. This is the reason the products of labor become commodities, social things whose qualities are at the same time perceptible and imperceptible by the senses. It is only a definite social relation between men that assumes, in their eyes, the fantastic form of a relation between things. ${ }^{149}$

Further, it is not just that social relations between humans are viewed as relations between things. As Lukács pointed out, the worker's "own labor becomes something objective and independent of him, something that controls him by virtue of an autonomy alien to man." 150

A world of commodities that the working class created confronts the working class as alien to them and alienated from them. The ability to perform work itself becomes a commodity in the reality, that is, capitalism, and, hence, in the mind of the worker. As Marx said: "What is characteristic of the capitalist age is that in the eyes of the laborer himself labor-power assumes the form of a commodity belonging to him. On the other hand it is only at this moment that the commodity form of the products of labor becomes general." 151

It is not just that this process of reification is going on. It is also that in being paid wages, both the worker and capitalist imagine that what is being paid for is the labor of the worker, rather than his or her labor power. This further form of mystification Marx captures when he says:

We see, further: The value of threes, by which a part only of the workingday - i.e., six hours' labor - is paid for, appears as the value or price of the whole working-day of 12 hours, which thus includes six hours unpaid for. The wage form thus extinguishes every trace of the division of the working-day into necessary labor and surplus-labor, into paid and unpaid labor. All labor appears as paid labor. In the corvee, the labor of the worker for himself, and his compulsory labor for his lord, differ in space and time in the clearest possible way. In slave labor, even that part of the working-day in which the slave is only replacing the value of his own means of existence, in which, therefore, in fact, he works for himself alone, appears as labor for his master. All the slave's labor appears as unpaid labor. In wage labor, on the contrary, even surplus-labor, or unpaid labor, appears as paid.

149 MARX, supra note 25, at 77.

150 LUKÁCS, supra note 32, at 87.

151 MARX, supra note 25, Chapter 4, Theories of Productive and Unproductive Labour available at https:/www.marxists.org/archive/marx/works/1863/theories-surplus-value/ch04.htm (last visited Jan. 7, 2016). 
There the property-relation conceals the labor of the slave for himself; here the money-relation conceals the unrequited labor of the wage laborer.

Hence, we may understand the decisive importance of the transformation of value and price of labor-power into the form of wages, or into the value and price of labor itself. This phenomenal form, which makes the actual relation invisible, and, indeed, shows the direct opposite of that relation, forms the basis of all the juridical notions of both laborer and capitalist, of all the mystifications of the capitalistic mode of production, of all its illusions as to liberty, of all the apologetic shifts of the vulgar economists. ${ }^{152}$

In other words, the appearance makes the actual invisible. Yet this doesn't make the appearance less real to those who experience it. As God is the creation of humanity, he or she not only appears to exist, he or she exists. It is precisely because the idea of God or the illusion of wages being paid for labor performed comes from the social relations of society that makes them real. As Marx said in relation to religion: "But man is no abstract being squatting outside the world. Man is the world of man-state, society. This state and this society produce religion, which is an inverted consciousness of the world, because they are an inverted world." ${ }^{153}$ So, too, with the capitalist mode of production-our current society-and the relations of production that see workers selling their labor power in the job market to capital. Labor is free in two senses. It is free from any means of subsistence and free to sell itself for subsistence, disguised as a wage seemingly paid for the actual labor performed. This inversion flows through the income tax system, too. The state and society produce income tax. It is both an inverted consciousness of the world and an actuality arising in an inverted world, a world of commodity production and circulation.

Money is the universal equivalent. This means that it becomes the mechanism for exchange by embodying the value that is then reflected in prices. Money performs many roles in capitalism. It is the ultimate reification in one sense, obscuring what is ultimately an abstract, unstable and shifting notion that is the relations of production within enterprises, exchange between enterprises, and the complex of political and state activities that operate to enforce its power as a physical fact. What is behind money is not a thing called money but the whole of the social relations of capitalism, or the complex of actions of real people who (re)produce the power of money as an external force. Money is an ideological proxy for the real power of real capitalists, politicians, and bureaucrats.

152 MarX, supra note 25, at 505-06.

153 Karl Marx, Introduction, in A Contribution to the Critique of Hegel's Philosophy OF RigHT available at https:/www.marxists.org/archive/marx/works/1843/critique-hpr/ intro.htm (last visited Jan. 7, 2016). 
It is money-in exchange, paid for wages, in capital, indeed in all its forms-that the tax system, including the income tax system, is concerned with.

The tax system is about real appearances but buries the essence. Tax mystification is as to the source of surplus value and, hence, of profit, the exploitative relationship between capital and labor and the categories of taxpayers, categories that attribute income earning to different bodies (e.g., businesses earning profit).

What the tax system deals with is the end result of the market exchange process. It hides the reality of the productive process, the process in which surplus value is created and how it is created. That reality, the reality of value, is obscured by the market and exchange. So the appearance is that workers are paid for all their labor and that capital creates profit. The reality is that it is the unpaid labor of workers that creates profit.

The tax system operates in the realm of appearances. It reflects the appearance that itself is a surface reality but obscures the essence of things. Marx called this dealing with appearances, which arises as a consequence of exchange on the market, "the fetishism of commodities" or "commodity fetishism." So, in the tax field, the monetized form of value in exchange disguises the reality of all the human relations. Further, in terms of income tax, the creation and distribution of the money form of that value becomes the basis for taxation by the capitalist state, not in the hands of the producers of the surplus value, or unpaid labor, but in the hands of those who expropriate the unpaid labor and to whom it is distributed in the process of circulation. This nonessence reality of companies earning profit, or banks interest, or landlords' rent is reification, which as Ollman told us is the process of "attributing an independent life to the various forms of value, people succeed in transferring to them certain powers for regulating their own existence." 154

To paraphrase Marx, the sphere of exchange is the realm of equivalence and equivalents. Buyers and sellers exchange as free agents. They are exchanging "their" property and receiving "their" rewards. They look only to themselves and their private interests.

These principles apply in the tax field too. The free market is the basis for income tax, a tax applying to the profit, interest, and rent that arises in exchange and to wages paid. The result is that this fetishism expresses itself in the income tax field with an attempt to tax "ordinary income" of companies and individuals. It doesn't distinguish between individuals on the basis of their class but on the basis of their income, an incomplete guide to class. It does distinguish between individuals and companies but hides the reality of exploitation and the creation of surplus value. It reifies the relationship by taxing companies as if they had created the surplus value when profit, that is, surface reflection of the surplus value, arises in the course of production and is realized in the process of circulation. It arises from the labor used in

154 Ollman, supra note 10, at 202. 
producing commodities for the market. Thus, the real human relationships are doubly hidden - in the labor process in production and in the realization process in circulation. Commodities replace humans and corporations make profit, with the human agency and human interactions hidden, except for the wise Board and CEO and other leaders. Company tax applies to the surplus value expropriated by an artificial entity whose existence is the humanization of the inhuman. It all seems so clear. We work 8, 9, or 10 hours a day and are paid for our labor. Yet this is merely an appearance, an illusion. We are paid for our ability to work, our labor power.

We have already been introduced, briefly, to the labor theory of value and the creation of surplus value in the production process. Marx summarized this well when he says:

In order to be able to extract value from the consumption of a commodity, our friend, Moneybags, must be so lucky as to find, within the sphere of circulation, in the market, a commodity, whose use-value possesses the peculiar property of being a source of value, whose actual consumption, therefore, is itself an embodiment of labor, and, consequently, a creation of value. The possessor of money does find on the market such a special commodity in capacity for labor or labor-power. ${ }^{155}$

The capitalist buys labor power around its value, "the value of the means of subsistence." As Marx puts it: "The value of labor-power is determined, as in the case of every other commodity, by the labor-time necessary for the production, and consequently the reproduction, of this special article." ${ }^{156}$ It is special because although capital purchases labor power, it is in the process of production that this labor power is set to work. It is in putting labor power to work that surplus value is created. What is missing from bourgeois economics and bourgeois law, including tax law and tax teaching, is the idea that it is the labor that creates value and what tax law, for example, does is reflect the illusory appearance of capitalism and reinforce by doing so the system's deeper reality. The classic income tax formula of taxable income being assessable income less allowable deductions disguises the reality of the creation of surplus value in the productive process and its realization on the market and redistribution in the circulation process. It disguises the fact that profit and interest and rent arise from the exploitation of labor and wages from the sale of labor power.

One of Adam Smith's key insights into judging a tax system was equity. The concept of income not only denies the class nature of its production out of the labor of workers but also makes the nature of our activity a generalized equivalent. We are all earning income rather than one class producing the surplus value through its labor. Shares in that value are then distributed to capital through the process of exchange, that is, the market,

\footnotetext{
155 MARX, supra note 25, at 164.

156 Id.
} 
based on their capital contributions. That "surplus become profit" or other forms of return on capital is then reinvested in labor power in the form of wages and machinery, factories, and the like. Like the villagers wondering what has happened to their cattle, we should march backwards to the essence to understand the reality. There is no Trinity. There is only one source of income and that is labor and the surplus value they create. By accepting the appearance and reinforcing that appearance at the expense of the essence, the income tax system acts both as a revenue raiser and as an ideological tool hammering home the message of the Holy Trinity.

\section{Conclusion}

Using the concepts and approaches that Marx has left us-concepts such as surplus value, labor power, use value and exchange value, things as processes and relations, totality, contradiction and change, the dialectical process including abstraction, the realization of surplus value on the market, and the tendency of the rate of profit to fall-we can clean the windows into the soul of income tax in Australia and in other developed capitalist countries. Armed with a knowledge and a constant process of deepening our understanding-for example, by looking through Marx's eyes at the process of capitalist production and circulation and the transformation of surplus value into profit, interest, rent, dividends, wages, and the like-we have the opportunity to clean off the centuries of caked-on filth on the windows into the soul of income tax. This wholesale cleaning could include projects not just looking at the system generally through the eyes of Marx but, for example, investigating the neoliberalization of tax policy and tax reform in Australia. It could also examine the role the Australian Labor Party plays, in government, in addressing tax the issues as part of managing capitalism, the question of rent taxes, how Australian tax reform and policy interrelates with, or is part of, wider global trends driven by global changes within capitalism, and why the Australian judiciary undermines or emasculates general anti-avoidance provisions. The foundations of the income tax system-income, source, residence, and the concept of taxpayer-could then be viewed using the tools outlined in this article. Let's use the tools we have discovered. Our journey has just begun. 